\title{
(6) OPEN ACCESS \\ The density of tobacco retailers in home and school environments and relationship with adolescent smoking behaviours in Scotland
}

\author{
N K Shortt, ${ }^{1}$ C Tisch, ${ }^{1}$ J Pearce, ${ }^{1}$ E A Richardson, ${ }^{1}$ R Mitchell ${ }^{2}$
}

${ }^{1}$ Centre for Research on Environment, Society and Health, School of Geosciences, University of Edinburgh, Edinburgh, UK

${ }^{2}$ Centre for Research on Environment, Society and Health, Institute of Health and Wellbeing, University of Glasgow, Glasgow, UK

Correspondence to Dr Niamh K Shortt, Centre for Research on Environment, Society and Health, School of Geosciences, University of Edinburgh, Edinburgh, Scotland EH8 9XP, UK; niamh.shortt@ed.ac.uk

Received 11 December 2013 Accepted 6 October 2014

Published Online First

5 November 2014

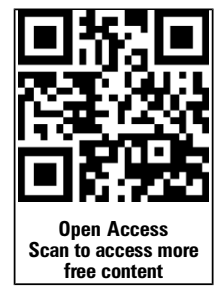

CrossMark

To cite: Shortt NK, Tisch C, Pearce J, et al. Tob Control 2016;25:75-82.

\section{ABSTRACT}

Background Neighbourhood retailing of tobacco products has been implicated in affecting smoking prevalence rates. Long-term smoking usually begins in adolescence and tobacco control strategies have often focused on regulating 'child spaces', such as areas in proximity to schools. This cross-sectional study examines the association between adolescent smoking behaviour and tobacco retail outlet density around home and school environments in Scotland.

Methods Data detailing the geographic location of every outlet registered to sell tobacco products in Scotland were acquired from the Scottish Tobacco Retailers Register and used to create a retail outlet density measure for every postcode. This measure was joined to individual responses of the Scottish Schools Adolescent Lifestyle and Substance Use Survey ( $n=20$ 446). Using logistic regression models, we explored the association between the density of retailers, around both home and school address, and smoking behaviours.

Results Those living in the areas of highest density of retailers around the home environment had 53\% higher odds of reporting having ever smoked $(95 \% \mathrm{Cl} 1.27$ to $1.85, p<0.001)$ and $47 \%$ higher odds of reporting current smoking $(95 \% \mathrm{Cl} 1.13$ to $1.91 \mathrm{p}<0.01)$. Conversely, those attending schools in areas of highest retail density had lower odds of having ever smoked (OR $0.66,95 \% \mathrm{Cl} 0.50$ to $0.86 \mathrm{p}<0.01)$ and lower odds of current smoking (OR $0.75,95 \% \mathrm{Cl} 0.59$ to $0.95, p<0.05)$.

Conclusions The density of tobacco retail outlets in residential neighbourhoods is associated with increased odds of both ever smoked and current smoking among adolescents in Scotland. Policymakers may be advised to focus on reducing the overall density of tobacco outlets, rather than concentrating on 'child spaces'.

\section{INTRODUCTION}

Various aspects of the local environment are important factors in explaining health and health-related behaviours, ${ }^{12}$ including smoking. ${ }^{3} 4$ Smoking behaviours and place are linked through two distinct pathways: place-based practices and place-based regulation/policy. ${ }^{4}$ Place-based practices that are relevant to understand smoking behaviour include levels of social capital, social practices, contagion and neighbourhood crime, disorder and stress. ${ }^{4}$ On the other hand place-based regulations and policy, which shape tobacco control, environmental opportunities and constraints for the availability and advertising of tobacco products, tend to be formed by national-level or state-level policies (eg, 'smoking bans'). One such environmental opportunity may be the density of tobacco retail outlets in neighbourhoods. A high density of such retailers may increase the ease with which individuals can access tobacco products and the local acceptability and normalisation of tobacco-related behaviours. Research has shown that tobacco outlet density is associated with higher odds of smoking in adults. ${ }^{5-8}$ It has also been suggested that the sight of retail outlets is associated with tobacco purchases and smoking frequency. ${ }^{5}$ Further research has explored the association between proximity to tobacco outlets and attempts to quit, confirming an association between the distance to outlets and the reduced likelihood of smoking cessation. ${ }^{9}{ }^{10}$

While most research exploring environmental drivers and smoking has focused on adults, the majority of adult smokers try their first cigarette before the age of $18 .{ }^{11}$ This makes tobacco misuse prevention in adolescence a widely endorsed public health goal. ${ }^{12}$ Those who start smoking at a younger age are more likely to become regular smokers in adulthood, ${ }^{13}$ and those who have not started smoking as a teenager are unlikely to ever become a smoker. ${ }^{14}$ Research on the association between tobacco retail density and adolescent smoking is less well established. Exploring tobacco outlet density in the home neighbourhood, research has reported higher odds of smoking over the past month ${ }^{15}$ and increased likelihood of smoking initiation $^{16}$ associated with increased tobacco outlet density. Higher rates of smoking prevalence among school pupils have been found in those attending schools in neighbourhoods of high tobacco retail outlet density. ${ }^{17}$ Further research has found that tobacco retail density around schools was positively associated with ever but not current smoking. ${ }^{18} 19$ These findings have prompted calls for new regulations to limit the density of tobacco outlets and the quantity of cigarette advertising in 'child spaces', particularly around schools. ${ }^{20} 21$

A limitation of previous research has been the exclusive focus on one aspect of an adolescent's environment, either the home or the school neighbourhood. This paper examines the relationship between adolescent smoking behaviours and tobacco retail outlet density in home and school neighbourhoods, after adjustment for individual, family-level and area-level variables. This research was conducted in Scotland, and as such makes an interesting comparison with the majority of previous research, which has been largely North American. In Scotland, adolescent smoking rates have fallen from $30 \%$ for 15 -year-old boys and girls in 1996 to $13 \%$ in $2010 .^{22}$ The Scottish 
Government has signalled its intent for a 'tobacco-free' Scotland by 2034 through the introduction of plain packaging, a review of smoking cessation services, making hospital grounds smokefree, a social marketing campaign on secondhand smoke and a peer education programme in schools. The current strategy, Creating a Tobacco-Free Generation, includes a focus on limiting the number of young people who take up smoking in the future by creating an environment where young people choose not to smoke. ${ }^{23}$ Therefore, it is important to explore the current environmental factors associated with adolescent smoking behaviours.

\section{METHODOLOGY}

This study consists of three stages: creating a tobacco retailer density measure; joining the density measure to individual records in the 2010 Scottish Schools Adolescent Lifestyle and Substance Use Survey (SALSUS); and analysing the association between adolescent behaviours and retail outlet density.

\section{Outlet data}

We obtained the addresses of all premises registered on the Scottish Tobacco Retailers Register as at 30 September 2012 $(n=11449)$. After cleaning and identifying duplicates, our final data set consisted of 10161 tobacco outlets.

We used Geographic Information Systems (GIS) to create measures of outlet density for every postcode in Scotland $(n=50466)$. Postcodes in the UK are based on postal addresses with each postcode corresponding to an average of 15 households. First, we mapped locations of the tobacco outlets based on the coordinates of their postcodes. We then undertook a Kernel Density Estimation (KDE). This transforms the spatial pattern of outlet locations into a continuous surface map which models the density of outlets. In brief, it begins by dividing all of Scotland into $100 \times 100 \mathrm{~m}$ grid cells. Next, for each cell, an assessment is made of the number and proximity of outlets within an $800 \mathrm{~m}$ radius (we tested the sensitivity of our choice of radius by running further analysis at 400 and $1000 \mathrm{~m}$ ). This radius was chosen as a plausible walking distance to get to an outlet. Outlets nearer the centre of the search window are given greater weight, with a decay function attributing less weight to outlets further away. ${ }^{24}$ Rather than reporting the number of outlets for each postcode, the KDE value represents the smoothed density of outlets. This has an advantage over traditional measures, such as number of outlets per postcode, as the influence of retailers located in adjoining postcodes is included and the measure is not therefore constrained by potential misclassification bias caused by arbitrarily defined boundaries. ${ }^{25}$ Postcode centroids were then placed on this density map, allowing us to extract the density value for each postcode. The final output of this process was a data set of proximity-weighted outlets per square kilometre $\left(\mathrm{km}^{2}\right)$ for every postcode in Scotland.

\section{Survey data}

SALSUS is a biennial national survey commissioned by the government to measure progress towards its target reductions of adolescent smoking, drinking and drug use. The 2010 wave was carried out between October 2010 and February 2011 surveying pupils from Secondary 2 (S2) and Secondary 4 (S4), most likely to be aged 13 and 15 , respectively. The final nationally representative sample of 37307 pupils equated to an individual pupil response rate of $91 \%$.

We examined two outcome variables; 'Ever smoked' and 'Current smoking'. The first was used because of evidence indicating that trying one cigarette in adolescence is one of the strongest predictors of going on to become a smoker. ${ }^{26}$ This outcome, referred to as 'ever smoked', has been explored elsewhere. ${ }^{27-30}$ In the survey, pupils were asked to select one of six responses related to smoking ranging from 'I have never smoked' to 'I usually smoke more than 6 cigarettes a week'. We merged the five responses which suggested that the respondent had, at one point in time, tried smoking. Our second outcome measured any current smoking regardless of frequency. ${ }^{15} \quad 31-33$ This outcome was taken from an affirmative response to the question 'Do you smoke at all nowadays?'

\section{Linking outlet density data with survey data}

When responding to the survey, pupils were asked to include their home and school postcodes. Of the 37307 pupils who completed the survey, 15963 did not include valid home and school postcodes. Pupils who did not provide both postcodes had to be removed from the analysis as it was not possible to assign a density value to these adolescents. Using the postcode identifiers on the SALSUS survey and our derived density data set, ISD Scotland attached a density value to every pupil with a legitimate home and school postcode, $57.2 \%$ of the entire sample $(n=21344)$. A further $898(4.2 \%)$ of the matched pupils were excluded as they did not respond to the outcome variables included in the analysis, resulting in a final sample of 20446 pupils.

We found that those excluded from the sample (16 861) were slightly more likely to be male $(53.7 \%$ vs $48.1 \%, \mathrm{p}<0.001)$, younger $(52.2 \%$ vs $51.7 \%, \mathrm{p}>0.05)$ and non-white $(7.6 \%$ vs $5.5 \%, \mathrm{p}<0.001)$. The overall rate of having ever smoked was higher among the excluded pupils compared with the included respondents $(36.1 \%$ vs $28.1 \%, \mathrm{p}<0.05)$. This was also the case for current smoking (15.4\% among excluded pupils vs $9.8 \%$ for included pupils, $\mathrm{p}<0.05)$. Furthermore, we ran models on a subset of our included pupils with characteristics corresponding to those of our missing group (young, non-white males) to see whether or not this group had a different relationship between smoking and outlet density compared to the rest of the sample. There was no significant difference, implying that the exclusion of this group is unlikely to have radically altered our models.

\section{Data analysis}

We ran a series of logistic regression models in STATA/IC V.12.0 (StataCorp, College Station, Texas, USA) to explore the association between our outcome variables and exposure to outlets after controlling for various covariates. To account for clustering of pupils within schools, we used the survey (svy) command. Pupils living in areas of zero density were used as the reference category in all of our models. The remaining pupils were divided into quartiles of density, both for the home $(>0-1.65$, $1.66-3.30,3.31-5.62,>5.63)$ and the school $(>0-1.93,1.94$ $3.78,3.79-6.71,>6.72)$. Model 1 included the density measure and individual level demographic variables (age group (by class year), sex and ethnicity). Model 2 added family variables: whether the individual received free school meals; self-perceived family wealth ( $1=$ very/quite well off, $2=$ average - not at all well off); family structure (eg, family with both parents, single parent family, etc) and parental smoking status. Finally, model 3 included two area-level measures: the Carstairs deprivation score (based on four census indicators: low social class, lack of car ownership, overcrowding and male unemployment) quintiles ( -4.58 to $1.60,-1.59$ to $0.33,0.34$ to $2.09,2.10$ to $4.69,4.70$ to 15.11 ) and an indicator of rurality (urban areas are classified by government as those settlements over 3000 people) (see 
Table 1 Descriptive statistics of Scottish Schools Adolescent Lifestyle and Substance Use Survey: 2010

\begin{tabular}{|c|c|c|c|c|c|c|}
\hline & \multirow{3}{*}{\multicolumn{2}{|c|}{ All pupils }} & \multicolumn{4}{|c|}{ Tobacco outcomes } \\
\hline & & & \multicolumn{2}{|c|}{ Ever smoked } & \multicolumn{2}{|c|}{ Current smokers } \\
\hline & & & \multicolumn{2}{|l|}{ Yes } & \multicolumn{2}{|l|}{ Yes } \\
\hline & n & Per cent & n & Per cent & n & Per cent \\
\hline All pupils & 20446 & 100 & 5745 & 28.1 & 2009 & 9.8 \\
\hline \multicolumn{7}{|l|}{ Tobacco outlet density: school } \\
\hline 1 (density=0) & 620 & 3.0 & 206 & 33.2 & 73 & 11.8 \\
\hline 2 (lowest density) & 5069 & 24.7 & 1418 & 28.0 & 495 & 9.8 \\
\hline 3 & 5337 & 26.1 & 1386 & 26.0 & 477 & 8.9 \\
\hline 4 & 4786 & 23.4 & 1401 & 29.3 & 512 & 10.7 \\
\hline 5 (highest density) & 4634 & 22.7 & 1334 & 28.8 & 452 & 9.8 \\
\hline \multicolumn{7}{|l|}{ Tobacco outlet density: home } \\
\hline 1 (density=0) & 2539 & 12.4 & 570 & 22.4 & 200 & 7.9 \\
\hline 2 (lowest density) & 4488 & 22.0 & 1145 & 25.5 & 399 & 8.9 \\
\hline 3 & 4457 & 21.8 & 1252 & 28.1 & 447 & 10.0 \\
\hline 4 & 4501 & 22.0 & 1352 & 30.0 & 477 & 10.6 \\
\hline 5 (highest density) & 4461 & 21.8 & 1426 & 32.0 & 486 & 10.9 \\
\hline \multicolumn{7}{|l|}{ Class year } \\
\hline Secondary 2 & 10563 & 51.7 & 1725 & 16.3 & 394 & 3.7 \\
\hline Secondary 4 & 9883 & 48.3 & 4020 & 40.7 & 1615 & 16.3 \\
\hline \multicolumn{7}{|l|}{ Sex } \\
\hline Male & 9844 & 48.1 & 2677 & 27.2 & 859 & 8.7 \\
\hline Female & 10580 & 51.7 & 3058 & 28.9 & 1145 & 10.8 \\
\hline Not stated & 22 & 0.1 & 10 & 45.5 & 5 & 22.7 \\
\hline \multicolumn{7}{|l|}{ Ethnicity } \\
\hline White & 19146 & 93.6 & 5350 & 27.9 & 1856 & 9.7 \\
\hline Non-white & 1133 & 5.5 & 332 & 29.3 & 131 & 11.6 \\
\hline Not stated & 167 & 0.8 & 63 & 37.7 & 22 & 13.2 \\
\hline \multicolumn{7}{|l|}{ Free school meals } \\
\hline Yes & 1889 & 9.2 & 780 & 41.3 & 306 & 16.2 \\
\hline No & 16293 & 79.7 & 4274 & 26.2 & 1422 & 8.7 \\
\hline Not stated & 2264 & 11.1 & 691 & 30.5 & 281 & 12.4 \\
\hline \multicolumn{7}{|l|}{ Self-perceived family wealth } \\
\hline Very/quite well off & 10068 & 49.2 & 2431 & 24.1 & 824 & 8.2 \\
\hline Average—not at all well off & 9597 & 46.9 & 3055 & 31.8 & 1092 & 11.4 \\
\hline Not stated & 781 & 3.8 & 259 & 33.2 & 93 & 11.9 \\
\hline \multicolumn{7}{|l|}{ Family structure } \\
\hline Single parent & 3845 & 18.8 & 1456 & 37.9 & 552 & 14.4 \\
\hline Step-parent (and one parent) & 1830 & 9.0 & 732 & 40.0 & 288 & 15.7 \\
\hline Both parents & 14017 & 68.6 & 3294 & 23.5 & 1071 & 7.6 \\
\hline Other & 426 & 2.1 & 167 & 39.2 & 71 & 16.7 \\
\hline Not stated & 328 & 1.6 & 96 & 29.3 & 27 & 8.2 \\
\hline \multicolumn{7}{|l|}{ Parental smoking status } \\
\hline No parent smokes & 11184 & 54.7 & 2153 & 19.3 & 590 & 5.3 \\
\hline At least one parent smokes daily & 6426 & 31.4 & 2829 & 44.0 & 1160 & 18.1 \\
\hline Not stated & 2836 & 13.9 & 763 & 26.9 & 259 & 9.1 \\
\hline \multicolumn{7}{|l|}{ Urban/rural status } \\
\hline Urban & 15670 & 76.6 & 4367 & 27.9 & 1491 & 9.5 \\
\hline Rural & 4738 & 23.2 & 1366 & 28.8 & 512 & 10.8 \\
\hline Missing & 38 & 0.2 & 12 & 31.6 & 6 & 15.8 \\
\hline \multicolumn{7}{|l|}{ Carstairs quintile } \\
\hline 1 (least deprived) & 4791 & 23.4 & 999 & 20.9 & 341 & 7.1 \\
\hline 2 & 4159 & 20.3 & 1087 & 26.1 & 382 & 9.2 \\
\hline 3 & 4394 & 21.5 & 1302 & 29.6 & 468 & 10.7 \\
\hline 4 & 3906 & 19.1 & 1218 & 31.2 & 411 & 10.5 \\
\hline 5 (most deprived) & 3173 & 15.5 & 1131 & 35.6 & 403 & 12.7 \\
\hline Missing & 23 & 0.1 & 8 & 34.8 & 4 & 17.4 \\
\hline
\end{tabular}




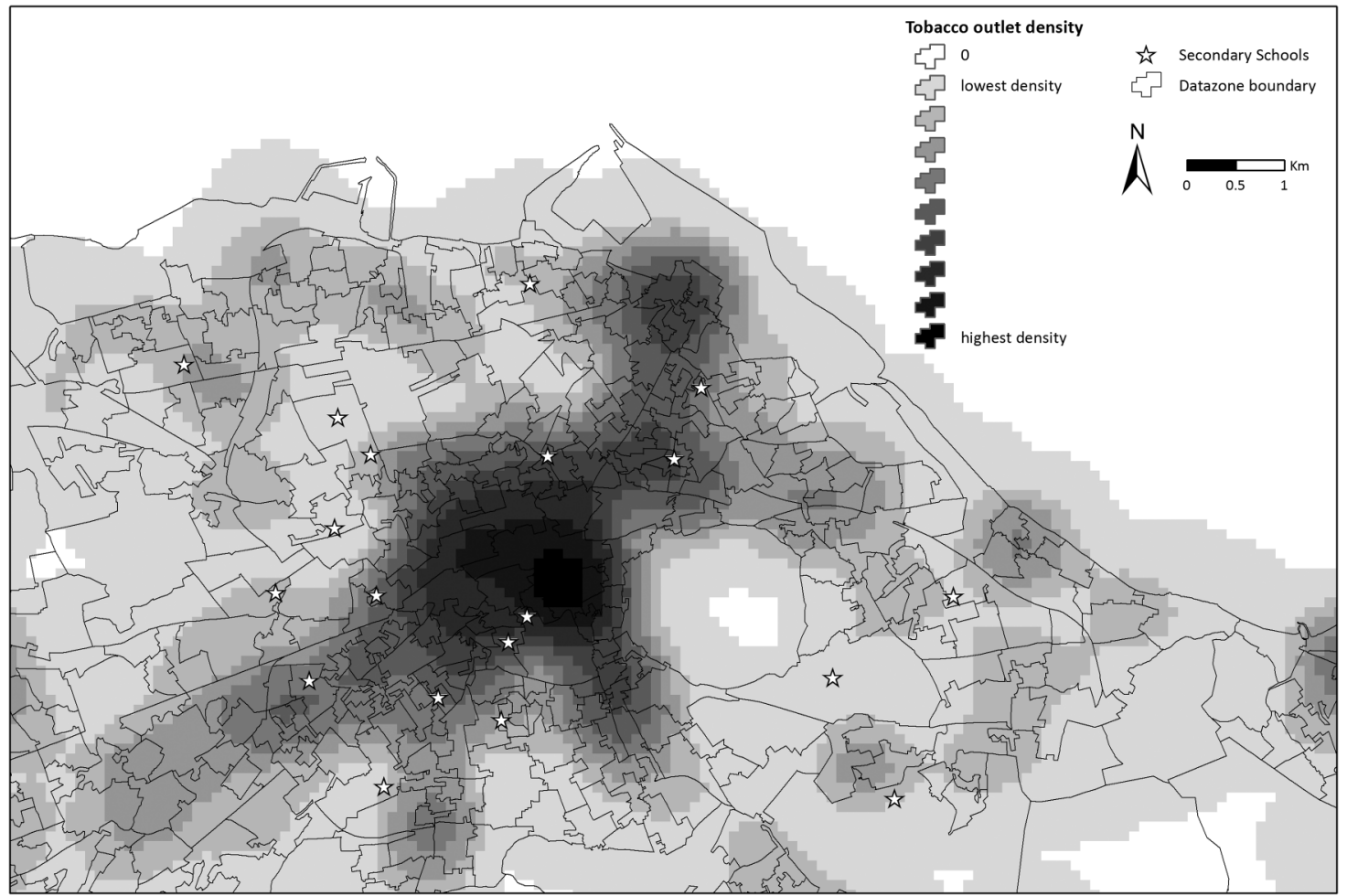

Figure 1 Map of tobacco outlet density in Edinburgh.

breakdown for all variables in table 1). In further analyses, we stratified the models by age and sex.

\section{RESULTS}

Density measures for tobacco outlets were created for each Scottish postcode. An example of our tobacco outlet density maps for the City of Edinburgh can be seen in figure 1 . The darker shaded areas are those with the highest density in the city centre and smaller pockets further out.

There was an overall prevalence rate of ever smoked of $28.1 \%$ : $16.3 \%$ of 13 -year-olds (S2) rising to $40.7 \%$ in 15 -year-olds (S4). $9.8 \%$ of pupils were current smokers, with this also increasing with age from $3.7 \%$ in S2 pupils to $16.3 \%$ in S4 pupils (table 1).

In model 1 , adjusting for individual level variables, there was a significant dose-response relationship between the density of tobacco retailers around the home environment and both current smoking and ever smoked (tables 2 and 3). The odds of current smoking ranged from 1.16 (CI 0.98 to $1.37 ; \mathrm{p}>0.05$ ) in the areas of lowest density to 1.44 (CI 1.19 to $1.73 ; \mathrm{p}<0.01$ ) in the areas of highest density (table 2). While not significant in the lowest density quartile, the results in all remaining quartiles were significant. Similar patterns are evident for ever smoked, ranging from 1.20 (CI 1.05 to $1.37 ; \mathrm{p}<0.001$ ) in areas of lowest density to 1.67 (CI 1.46 to $1.90 ; \mathrm{p}<0.001)$ in areas of highest density around the home (table 3). After further controlling for family and area level variables, a significant relationship remained for both ever smoked and current smoking and retail density around the home. For current smoking, the odds were $47 \%$ higher in the highest density quartile compared to having no outlets in the area (OR 1.47, CI 1.13 to $1.91 ; \mathrm{p}<0.01)$. For ever smoked, those in areas with the highest density had 53\% higher odds (OR 1.53, CI 1.27 to 1.85 ; $\mathrm{p}<0.001$ ) of having ever tried smoking compared with those with no retail outlets in their immediate vicinity.
The relationship with the school environment was in the opposite direction. In model 1 (again controlling for individual level variables), an increased density of tobacco retailers near schools was associated with lower odds of having ever smoked and current smoking, but neither model was significant. After controlling for all confounders, we see significantly lower odds of having ever smoked (OR 0.66, CI 0.50 to $0.86 ; \mathrm{p}<0.01$ ). Furthermore, in the fully adjusted model, pupils attending schools in the highest density had significantly lower odds (OR 0.75 , CI 0.59 to $0.95, \mathrm{p}<0.05$ ) of being a current smoker compared with those with no retail outlets around their school.

It is important to note that in the models we have added variables which, following a review of the literature, have been identified as important predictors of adolescent smoking. In all of our models, for both home and school density, two variables (having both parents living at home and not receiving free school meals) were consistently related with lower odds of adolescent smoking and one variable, having a parent who smokes daily, with higher odds.

To examine whether tobacco retail density had differential effects among younger or older populations and males or females, we further stratified our analysis by age and sex. For both 13-year-olds and 15-year-olds, the general patterns remained the same for both home and school environments.

\section{DISCUSSION}

This is the first UK study to examine the association between the neighbourhood density of tobacco retailers and adolescent smoking behaviours at a national level. We found the anticipated relationship surrounding an adolescent's home; a higher density of tobacco retailers was associated with higher odds of an adolescent engaging in both having ever smoked and current smoking. These findings are consistent with the majority of previous studies, mostly from North America, considering the 
Table 2 Odds of current smoking in school and home environments

\begin{tabular}{|c|c|c|c|c|c|c|}
\hline & \multicolumn{2}{|l|}{ Model 1} & \multicolumn{2}{|l|}{ Model 2} & \multicolumn{2}{|l|}{ Model 3} \\
\hline & $\begin{array}{l}\text { Home } \\
\text { OR } 95 \% \mathrm{Cl}\end{array}$ & $\begin{array}{l}\text { School } \\
\text { OR } 95 \% \mathrm{Cl}\end{array}$ & $\begin{array}{l}\text { Home } \\
\text { OR } 95 \% \mathrm{Cl}\end{array}$ & $\begin{array}{l}\text { School } \\
\text { OR } 95 \% \mathrm{Cl}\end{array}$ & $\begin{array}{l}\text { Home } \\
\text { OR } 95 \% \mathrm{Cl}\end{array}$ & $\begin{array}{l}\text { School } \\
\text { OR } 95 \% \mathrm{Cl}\end{array}$ \\
\hline \multicolumn{7}{|l|}{ Tobacco outlet density } \\
\hline 1 (density=0) & 1.00 & 1.00 & 1.00 & 1.00 & 1.00 & 1.00 \\
\hline 2 (lowest density) & $1.16(0.98$ to 1.37$)$ & 0.85 (0.54 to 1.34$)$ & $1.10(0.90$ to 1.34$)$ & 0.77 (0.58 to 1.04$)$ & $1.35(1.10 \text { to } 1.67)^{*}$ & $0.77(0.61 \text { to } 0.98)^{*}$ \\
\hline 3 & $1.32(1.11 \text { to } 1.58)^{*}$ & $0.77(0.49$ to 1.23$)$ & 1.11 (0.91 to 1.37$)$ & $0.69(0.51 \text { to } 0.92)^{*}$ & $1.41(1.11 \text { to } 1.79)^{*}$ & $0.70(0.55 \text { to } 0.89)^{*}$ \\
\hline 4 & $1.42(1.19 \text { to } 1.70)^{*}$ & 0.92 (0.58 to 1.47$)$ & 1.14 (0.93 to 1.39$)$ & $0.73(0.54 \text { to } 0.99)^{*}$ & $1.41(1.11 \text { to } 1.79)^{*}$ & $0.73(0.56 \text { to } 0.94)^{*}$ \\
\hline 5 (highest density) & $1.44(1.19 \text { to } 1.73)^{*}$ & 0.83 (0.52 to 1.32 ) & 1.14 (0.93 to 1.41$)$ & $0.74(0.55 \text { to } 0.99)^{*}$ & $1.47(1.13 \text { to } 1.91)^{*}$ & $0.75(0.59 \text { to } 0.95)^{*}$ \\
\hline Trend & $1.09(1.05 \text { to } 1.13)^{*}$ & $1.00(0.94$ to 1.06$)$ & 1.02 (0.98 to 1.07$)$ & 0.97 (0.91 to 1.04$)$ & $1.06(1.00 \text { to } 1.12)^{*}$ & 0.98 (0.92 to 1.04$)$ \\
\hline \multicolumn{7}{|l|}{ Class year } \\
\hline Secondary 2 (age 13) & 1.00 & 1.00 & 1.00 & 1.00 & 1.00 & 1.00 \\
\hline Secondary 4 (age 15) & $5.06(4.37 \text { to } 5.87)^{*}$ & $5.05(4.36 \text { to } 5.85)^{*}$ & $5.48(4.65 \text { to } 6.47)^{*}$ & $5.48(4.64 \text { to } 6.47)^{*}$ & $5.49(4.65 \text { to } 6.49)^{*}$ & $5.50(4.66 \text { to } 6.50)^{*}$ \\
\hline \multicolumn{7}{|l|}{ Sex } \\
\hline Female & 1.00 & 1.00 & 1.00 & 1.00 & 1.00 & 1.00 \\
\hline Male & $1.30(1.16 \text { to } 1.47)^{*}$ & $1.30(1.15 \text { to } 1.46)^{*}$ & $1.40(1.22 \text { to } 1.61)^{*}$ & $1.40(1.22 \text { to } 1.60)^{*}$ & $1.39(1.21 \text { to } 1.60)^{*}$ & $1.38(1.21 \text { to } 1.59)^{*}$ \\
\hline \multicolumn{7}{|l|}{ Ethnicity } \\
\hline White & 1.00 & 1.00 & 1.00 & 1.00 & 1.00 & 1.00 \\
\hline Non-white & $1.28(1.04 \text { to } 1.56)^{*}$ & $1.30(1.06 \text { to } 1.59)^{*}$ & $1.32(1.00 \text { to } 1.74)^{*}$ & $1.32(1.00 \text { to } 1.75)^{*}$ & $1.37(1.04 \text { to } 1.80)^{*}$ & $1.37(1.04 \text { to } 1.80)^{*}$ \\
\hline \multicolumn{7}{|l|}{ Free school meals } \\
\hline Yes & & & 1.00 & 1.00 & 1.00 & 1.00 \\
\hline No & & & $0.72(0.60 \text { to } 0.86)^{*}$ & $0.71(0.60 \text { to } 0.85)^{*}$ & $0.73(0.61 \text { to } 0.88)^{*}$ & $0.73(0.61 \text { to } 0.87)^{*}$ \\
\hline \multicolumn{7}{|l|}{ Self-perceived family wealth } \\
\hline Very /quite well off & & & 1.00 & 1.00 & 1.00 & 1.00 \\
\hline Average—not at all well off & & & 1.01 (0.89 to 1.14$)$ & 1.01 (0.89 to 1.14$)$ & $1.00(0.88$ to 1.13$)$ & $1.00(0.88$ to 1.13$)$ \\
\hline \multicolumn{7}{|l|}{ Family structure } \\
\hline Single parent & & & 1.00 & 1.00 & 1.00 & 1.00 \\
\hline Step-parent (and one parent) & & & $1.04(0.87$ to 1.25$)$ & $1.04(0.87$ to 1.24$)$ & $1.04(0.87$ to 1.25$)$ & $1.03(0.86$ to 1.24$)$ \\
\hline Both parents & & & $0.68(0.59 \text { to } 0.78)^{*}$ & $0.67(0.58 \text { to } 0.77)^{*}$ & $0.68(0.59 \text { to } 0.78)^{*}$ & $0.67(0.58 \text { to } 0.77)^{*}$ \\
\hline Other & & & 1.32 (0.88 to 1.97$)$ & $1.30(0.87$ to 1.95$)$ & $1.29(0.86$ to 1.93$)$ & $1.26(0.84$ to 1.89$)$ \\
\hline \multicolumn{7}{|l|}{ Parental smoking status } \\
\hline No parent smokes & & & 1.00 & 1.00 & 1.00 & 1.00 \\
\hline $\begin{array}{l}\text { At least one parent smokes } \\
\text { daily }\end{array}$ & & & $3.39(2.99 \text { to } 3.85)^{*}$ & $3.42(3.01 \text { to } 3.89)^{*}$ & $3.31(2.91 \text { to } 3.77)^{*}$ & $3.33(2.92 \text { to } 3.78)^{*}$ \\
\hline \multicolumn{7}{|l|}{ Urban/rural status } \\
\hline Urban & & & & & 1.00 & 1.00 \\
\hline Rural & & & & & $1.52(1.28 \text { to } 1.81)^{*}$ & $1.33(1.14 \text { to } 1.55)^{*}$ \\
\hline \multicolumn{7}{|l|}{ Carstairs quintile } \\
\hline 1 (least deprived) & & & & & 1.00 & 1.00 \\
\hline 2 & & & & & $1.03(0.81$ to 1.30$)$ & $1.04(0.83$ to 1.31$)$ \\
\hline 3 & & & & & $1.26(1.01 \text { to } 1.58)^{*}$ & $1.30(1.05 \text { to } 1.60)^{*}$ \\
\hline 4 & & & & & $1.14(0.90$ to 1.45$)$ & $1.20(0.96$ to 1.51$)$ \\
\hline 5 (most deprived) & & & & & 1.27 (0.99 to 1.62$)$ & $1.35(1.07 \text { to } 1.69)^{*}$ \\
\hline
\end{tabular}

$95 \%$ Cls in brackets, ${ }^{*} \mathrm{p}<0.05$.

importance of the local retailing environment and smoking behaviour. $^{34} 35$ However, our findings did not support earlier work which tended to find a higher density of tobacco retailers around schools to be positively associated with smoking behaviour $^{15}{ }^{17-19}$; indeed, we found lower odds of having ever smoked and current smoking in pupils attending schools in areas with the highest density of tobacco retailers. This finding might be explained by higher levels of surveillance (and compliance) among retailers in proximity to schools. Adolescents in the UK attempting to purchase tobacco in proximity to schools are likely to be dressed in school uniform (unlike adolescents in North America) which indicates to retailers that they are underage.

Our research responds to calls for more evidence on the association between retail outlets and adolescent smoking behaviours. ${ }^{27}$ Consistent with previous research, we acknowledge the importance of individual-level and family-level risk factors on adolescent smoking, including family structure, poverty (as measured though Free School Meals) and parental smoking status, but also emphasise significant area-level effects in the form of tobacco outlet density. We recognise that there are other smoking-related outcomes which could be altered by the density of outlets in a neighbourhood. An increased density of outlets in a neighbourhood may shape normative structures of behaviour including attitudes towards tobacco and subjective norms. Such attitudes and norms in adolescents have been shown to predict smoking in the future. ${ }^{36}{ }^{37}$ More research is required to explore the impact of such density on adolescent behaviour more indirectly through the formation of social norms, the social acceptability of smoking and local attitudes to risky behaviours. 
Table 3 Odds of having ever smoked in school and home environments

\begin{tabular}{|c|c|c|c|c|c|c|}
\hline & \multicolumn{2}{|l|}{ Model 1} & \multicolumn{2}{|l|}{ Model 2} & \multicolumn{2}{|l|}{ Model 3} \\
\hline & $\begin{array}{l}\text { Home } \\
\text { OR } 95 \% \mathrm{Cl}\end{array}$ & $\begin{array}{l}\text { School } \\
\text { OR } 95 \% \mathrm{Cl}\end{array}$ & $\begin{array}{l}\text { Home } \\
\text { OR } 95 \% \mathrm{Cl}\end{array}$ & $\begin{array}{l}\text { School } \\
\text { OR } 95 \% \mathrm{Cl}\end{array}$ & $\begin{array}{l}\text { Home } \\
\text { OR } 95 \% \mathrm{Cl}\end{array}$ & $\begin{array}{l}\text { School } \\
\text { OR } 95 \% \mathrm{Cl}\end{array}$ \\
\hline \multicolumn{7}{|l|}{ Tobacco outlet density } \\
\hline 1 (density=0) & 1.00 & 1.00 & 1.00 & 1.00 & 1.00 & 1.00 \\
\hline 2 (lowest density) & $1.20(1.05 \text { to } 1.37)^{*}$ & 0.80 (0.48 to 1.32$)$ & $1.19(1.03 \text { to } 1.38)^{*}$ & $0.72(0.51$ to 1.00$)$ & $1.42(1.20 \text { to } 1.67)^{*}$ & $0.70(0.53 \text { to } 0.93)^{*}$ \\
\hline 3 & $1.38(1.21 \text { to } 1.57)^{*}$ & $0.72(0.43$ to 1.19$)$ & $1.22(1.05 \text { to } 1.41)^{*}$ & $0.64(0.46 \text { to } 0.90)^{*}$ & $1.45(1.22 \text { to } 1.71)^{*}$ & $0.63(0.47 \text { to } 0.83)^{*}$ \\
\hline 4 & $1.53(1.35 \text { to } 1.74)^{*}$ & 0.83 (0.50 to 1.38$)$ & $1.23(1.05 \text { to } 1.43)^{*}$ & $0.67(0.48 \text { to } 0.94)^{*}$ & $1.42(1.19 \text { to } 1.69)^{*}$ & $0.63(0.48 \text { to } 0.84)^{*}$ \\
\hline 5 (highest density) & $1.67(1.46 \text { to } 1.90)^{*}$ & $0.82(0.50$ to 1.35$)$ & $1.31(1.13 \text { to } 1.52)^{*}$ & $0.68(0.49 \text { to } 0.95)^{*}$ & $1.53(1.27 \text { to } 1.85)^{*}$ & $0.66(0.50 \text { to } 0.86)^{*}$ \\
\hline Trend & $1.13(1.10 \text { to } 1.16)^{*}$ & 1.01 (0.96 to 1.06$)$ & $1.05(1.02 \text { to } 1.09)^{*}$ & 0.97 (0.92 to 1.02$)$ & $1.06(1.02 \text { to } 1.11)^{*}$ & 0.96 (0.91 to 1.01$)$ \\
\hline \multicolumn{7}{|l|}{ Class year } \\
\hline Secondary 2 (age 13) & 1.00 & 1.00 & 1.00 & 1.00 & 1.00 & 1.00 \\
\hline Secondary 4 (age 15) & $3.55(3.24 \text { to } 3.88)^{*}$ & $3.52(3.22 \text { to } 3.85)^{*}$ & $3.84(3.49 \text { to } 4.24)^{*}$ & $3.84(3.49 \text { to } 4.23)^{*}$ & $3.85(3.50 \text { to } 4.25)^{*}$ & $3.86(3.51 \text { to } 4.26)^{*}$ \\
\hline \multicolumn{7}{|l|}{ Sex } \\
\hline Female & 1.00 & 1.00 & 1.00 & 1.00 & 1.00 & 1.00 \\
\hline Male & $1.11(1.02 \text { to } 1.20)^{*}$ & $1.10(1.02 \text { to } 1.20)^{*}$ & $1.15(1.05 \text { to } 1.26)^{*}$ & $1.14(1.04 \text { to } 1.25)^{*}$ & $1.14(1.04 \text { to } 1.25)^{*}$ & $1.14(1.04 \text { to } 1.25)^{*}$ \\
\hline \multicolumn{7}{|l|}{ Ethnicity } \\
\hline White & 1.00 & 1.00 & 1.00 & 1.00 & 1.00 & 1.00 \\
\hline Non-white & 1.10 (0.95 to 1.27$)$ & 1.12 (0.97 to 1.30$)$ & 1.18 (0.99 to 1.41$)$ & $1.20(1.00 \text { to } 1.43)^{*}$ & $1.22(1.02 \text { to } 1.45)^{*}$ & $1.22(1.02 \text { to } 1.45)^{*}$ \\
\hline \multicolumn{7}{|l|}{ Free school meals } \\
\hline Yes & & & 1.00 & 1.00 & 1.00 & 1.00 \\
\hline No & & & $0.70(0.61 \text { to } 0.80)^{*}$ & $0.69(0.60 \text { to } 0.78)^{*}$ & $0.72(0.63 \text { to } 0.83)^{*}$ & $0.72(0.63 \text { to } 0.82)^{*}$ \\
\hline \multicolumn{7}{|l|}{ Self-perceived family wealth } \\
\hline Very/quite well off & & & 1.00 & 1.00 & 1.00 & 1.00 \\
\hline Average—not at all well off & & & $1.08(1.01 \text { to } 1.17)^{*}$ & $1.08(1.01 \text { to } 1.17)^{*}$ & 1.07 (0.99 to 1.15$)$ & $1.07(0.99$ to 1.15$)$ \\
\hline \multicolumn{7}{|l|}{ Family structure } \\
\hline Single parent & & & 1.00 & 1.00 & 1.00 & 1.00 \\
\hline Step-parent (and one parent) & & & $1.04(0.91$ to 1.20$)$ & $1.04(0.90$ to 1.19$)$ & $1.04(0.91$ to 1.20$)$ & $1.03(0.90$ to 1.19$)$ \\
\hline Both parents & & & $0.65(0.59 \text { to } 0.73)^{*}$ & $0.65(0.58 \text { to } 0.72)^{*}$ & $0.65(0.59 \text { to } 0.73)^{*}$ & $0.65(0.58 \text { to } 0.72)^{*}$ \\
\hline Other & & & $1.36(1.06 \text { to } 1.74)^{*}$ & $1.34(1.04 \text { to } 1.72)^{*}$ & $1.32(1.03 \text { to } 1.70)^{*}$ & $1.30(1.01 \text { to } 1.67)^{*}$ \\
\hline \multicolumn{7}{|l|}{ Parental smoking status } \\
\hline No parent smokes & & & 1.00 & 1.00 & 1.00 & 1.00 \\
\hline $\begin{array}{l}\text { At least one parent smokes } \\
\text { daily }\end{array}$ & & & $2.95(2.69 \text { to } 3.23)^{*}$ & $3.00(2.74 \text { to } 3.28)^{*}$ & $2.83(2.59 \text { to } 3.10)^{*}$ & $2.85(2.60 \text { to } 3.11)^{*}$ \\
\hline \multicolumn{7}{|l|}{ Urban/rural status } \\
\hline Urban & & & & & 1.00 & 1.00 \\
\hline Rural & & & & & $1.43(1.27 \text { to } 1.62)^{*}$ & $1.23(1.09 \text { to } 1.37)^{*}$ \\
\hline \multicolumn{7}{|l|}{ Carstairs quintile } \\
\hline 1 (least deprived) & & & & & 1.00 & 1.00 \\
\hline 2 & & & & & $1.11(0.94$ to 1.30$)$ & $1.13(0.97$ to 1.32$)$ \\
\hline 3 & & & & & $1.27(1.07 \text { to } 1.49)^{*}$ & $1.31(1.12 \text { to } 1.54)^{*}$ \\
\hline 4 & & & & & $1.32(1.12 \text { to } 1.56)^{*}$ & $1.40(1.20 \text { to } 1.64)^{*}$ \\
\hline 5 (most deprived) & & & & & $1.43(1.23 \text { to } 1.67)^{*}$ & $1.54(1.31 \text { to } 1.79)^{*}$ \\
\hline
\end{tabular}

$95 \%$ Cls in brackets, ${ }^{*} \mathrm{p}<0.05$.

Our study has limitations. First, we use cross-sectional data and hence can only infer association, rather than causation. Second, we do not have data on adolescent purchasing patterns, and as such we do not know whether these adolescents are using retail outlets to purchase their tobacco or are relying on informal networks as their main source. Third, our final sample included $54.8 \%$ of SALSUS respondents as we did not include those without a spatial identifier (postcode), and those that did not respond to the smoking questions. The deletion of these results may have resulted in either overstating or understating our final results. We did, however, assess whether pupils in our sample who had characteristics associated with missing postcode data (younger non-white males) seemed to have different relationships between smoking status and tobacco environment, compared with the rest of the sample. They did not-which implies that the exclusion of pupils with missing postcodes is unlikely to have radically altered or biased our models. Finally, there are various factors that may influence whether or not an adolescent chooses to smoke, with the density of outlets being just one. As far as possible, we have tried to control for these at the individual, family and area level, but recognise that there may be other factors shaping young people's smoking behaviour.

There is increased interest in the ways in which our environment may influence our behaviours, and this is particularly important in adolescence when such behaviours are formed. In particular, this is the first study that has included a measure of home and school environments. In doing so, we offer a better conceptualisation of the environment by acknowledging that 
adolescents are exposed to place-based characteristics in a range of settings. This research indicates the importance of the retail environment more generally, not just that around schools or in so-called child spaces, but across the total environment.

The results of this research are important from a public policy and public health perspective. A 2012 report, published by the Royal College of Physicians and the UK Centre for Tobacco Control Studies, reported little or no evidence base for retail interventions but suggested that restricting the number/density of outlets in a locality could have an impact on smoking uptake and perpetuation. These findings support this suggestion and confirm that in Scotland the density of tobacco outlets in a neighbourhood is positively associated with increased odds of related risky behaviours in adolescents. The fact that adolescents in areas with the greatest density of outlets in their home environment are more likely to try smoking is critical, particularly when we consider the strength of evidence suggesting that these adolescents, who even try smoking once, are more likely to establish habitual risky behaviours. This evidence does not support a reduction of retailers solely in 'child spaces', such as school neighbourhoods. Instead, tobacco control policy should consider regulating the density of tobacco outlets across all neighbourhoods to reduce the likelihood of smoking and smoking initiation in adolescents.

\section{What this paper adds}

\section{What is already known on the subject}

- Research has shown that tobacco retail outlet density in residential neighbourhoods is associated with higher odds of smoking.

- Further research has demonstrated higher rates of smoking among pupils attending schools in neighbourhoods of high tobacco retail outlet density.

What important gaps exist in knowledge on this subject

- A limitation of previous research has been the exclusive focus on one aspect of an adolescent's environment, either the home or the school neighbourhood.

\section{What this study adds}

- This national level study explores the association between tobacco outlet density and adolescent smoking behaviours in home and school neighbourhoods.

- Adolescents living in areas of high tobacco outlet density have higher odds of both having ever smoked and current smoking.

- In contrast, adolescents attending schools in areas of highest density had lower odds of having ever smoked and current smoking.

- This evidence does not support a reduction of retailers solely in 'child spaces', such as school neighbourhoods. Instead, tobacco control policy should consider regulating the density of tobacco outlets across all neighbourhoods to reduce the likelihood of smoking and smoking initiation in adolescents.

Acknowledgements Many thanks to Helena Tunstall and Esther Rind for comments on an earlier draft. Many thanks also to the anonymous referees for their invaluable comments.

Contributors NKS, JP, EAR and RM developed the initial concept for the research. CT collected the data, conducted the data analysis and assisted with the writing of the manuscript. NKS was involved in all stages and drafted the paper. JP, EAR and RM assisted in data interpretation and provided a critique on earlier versions. All authors approved the final manuscript.
Funding This research was funded by the Scottish Collaboration for Public Health Research and Policy (SCPHRP).

\section{Competing interests None.}

Ethics approval This study had ethical approval from the School of Geosciences, University of Edinburgh ethics board.

Provenance and peer review Not commissioned; externally peer reviewed.

Data sharing statement The density measures used in this study are available from the corresponding author.

Open Access This is an Open Access article distributed in accordance with the Creative Commons Attribution Non Commercial (CC BY-NC 3.0) license, which permits others to distribute, remix, adapt, build upon this work non-commercially, and license their derivative works on different terms, provided the original work is properly cited and the use is non-commercial. See: http://creativecommons.org/ licenses/by-nc/3.0/

\section{REFERENCES}

1 Diehr P, Koepsell T, Cheadle A, et al. Do communities differ in health behaviors. J Clin Epidemiol 1993;46:1141-9.

2 Ellaway A, Macintyre $S$. Does where you live predict health related behaviours? A case study in Glasgow. Health Bull (Edinb) 1996;54:443-6.

3 Poland B, Frohlich K, Haines RJ, et al. The social context of smoking: the next frontier in tobacco control? Tob Control 2006;15:59-63.

4 Pearce J, Barnett R, Moon G. Sociospatial inequalities in health-related behaviours: pathways linking place and smoking. Prog Hum Geography 2012;36:3-24.

5 Burton S, Spanjaard D, Hoek J. An investigation of tobacco retail outlets as a cue for smoking. AMJ 2013;21:234-9.

6 Chuang YC, Cubbin C, Ahn D, et al. Effects of neighbourhood socioeconomic status and convenience store concentration on individual level smoking. J Epidemiol Community Health 2005;59:568-73.

7 Paul CL, Mee KJ, Judd TM, et al. Anywhere, anytime: retail access to tobacco in New South Wales and its potential impact on consumption and quitting. Soc Sci Med 2010;71:799-806.

8 Pearce J, Hiscock R, Moon G, et al. The neighbourhood effects of geographical access to tobacco retailers on individual smoking behaviour. J Epidemiol Community Health 2009;63:69-77.

9 Halonen Jl, Kivimäki M, Kouvonen A, et al. Proximity to a tobacco store and smoking cessation: a cohort study. Tob Control 2014;23:146-51.

10 Reitzel LR, Cromley EK, Li Y, et al. The effect of tobacco outlet density and proximity on smoking cessation. Am J Public Health 2011;101:315-20.

11 U.S. Department of Health and Human Services. Preventing tobacco use among youth and young adults: a report of the surgeon general. Atlanta: Department of Health and Human Services, Centers for Disease Control and Prevention, Office on Smoking and Health, 2012.

12 Mosbach $\mathrm{P}$, Leventhal H. Peer group identification and smoking: implications for intervention. J Abnorm Psychol 1988;97:238-45.

13 Tyas SL, Pederson LL. Psychosocial factors related to adolescent smoking: a critical review of the literature. Tob Control 1998;7:409-20.

14 Kessler DA. Nicotine addiction in young people. N Engl J Med 1995;333:186-9.

15 Novak SP, Reardon SF, Raudenbush SW, et al. Retail tobacco outlet density and youth cigarette smoking: a propensity-modeling approach. Am J Public Health 2006:96:670-6.

16 Pokorny LA, Schoeny ME. The relation of retail tobacco availability to initiation and continued smoking. J Clin Child Adolesc Psychol 2003;32:193-204.

17 Henriksen L, Feighery EC, Schleicher NC, et al. Is adolescent smoking related to the density and proximity of tobacco outlets and retail cigarette advertising near schools? Prev Med 2008;47:210-14.

18 Adams ML, Jason LA, Pokorny $S$, et al. Exploration of the link between tobacco retailers in school neighborhoods and student smoking. J Sch Health 2013;83:112-18.

19 McCarthy WJ, Mistry R, Lu Y, et al. Density of tobacco retailers near schools: effects on tobacco use among students. Am J Public Health 2009;99:2006-13.

20 Ashe $\mathrm{M}$, Jernigan $\mathrm{D}, \mathrm{Klinc} \mathrm{R}$, et al. Land use planning and the control of alcohol, tobacco, firearms, and fast food restaurants. Am J Public Health 2003;93:1404-8.

21 Institute of Medicine. Ending the tobacco problem: a blueprint for the Nation. The National Academies Press, 2007.

22 Black C, Eunson J, Sewel K, et al. Scottish Schools Adolescent Lifestyle and Substance Use Survey (SALSUS) national report: smoking, drinking and drug use among 13 and 15-year-olds in Scotland in 2010. Edinburgh: NHS National Services Scotland, 2011.

23 Scottish Government. Creating a tobacco-free generation: a tobacco control strategy for Scotland. Edinburgh, 2013.

24 Carlos H, Shi X, Sargent J, et al. Density estimation and adaptive bandwidths: a primer for public health practitioners. Int I Health Geogr 2010;9:39.

25 Kwan M-P. The uncertain geographic context problem. Ann Assoc Am Geographers 2012;102:958-68. 
$26 \mathrm{MCNeill} A D$, Jarvis MJ, Stapleton JA, et al. Prospective study of factors predicting uptake of smoking in adolescents. J Epidemiol Community Health 1988;43:72-8.

27 Adachi-Mejia AM, Carlos HA, Berke EM, et al. A comparison of individual versus community influences on youth smoking behaviours: a cross-sectional observational study. BMJ Open 2012;2:e000767.

28 Feighery EC, Henriksen L, Wang Y, et al. An evaluation of four measures of adolescents' exposure to cigarette marketing in stores. Nicotine Tob Res 2006;8:751-9.

29 Henriksen L, Schleicher NC, Feighery EC, et al. Longitudinal study of exposure to retail cigarette advertising and smoking initiation. Pediatrics 2010;126:2009-3021.

30 Schooler C, Feighery E, Flora JA. Seventh graders' self-reported exposure to cigarette marketing and its relationship to their smoking behavior. Am J Public Health 1996;86:1216-21.

31 Braverman MT, Aaro LE. Adolescent smoking and exposure to tobacco marketing under a tobacco advertising ban: findings from 2 Norwegian national samples. $A m$ J Public Health 2004;94:1230-8.
32 Hersch J. Teen smoking behavior and the regulatory environment. Duke Law J 1998;47:1143-70.

33 Lakon CM, Hipp JR, Timberlake DS. The social context of adolescent smoking: a systems perspective. Am J Public Health 2010;100:1218-28.

34 Chuang J-C, Cubbin C, Ahn D, et al. Effects of neighbourhood socioeconomic status and convenience store concentration on individual level smoking. J Epidemiol Community Health 2005;59:568-73.

35 Lipperman-Kreda S, Grube JW, Friend KB. Contextual and community factors associated with youth access to cigarettes through commercial sources. Tob Control 2014;23:39-44.

36 Larsen JT, Cohen LM. Smoking attitudes, intentions, and behaviors among college student smokers: positivity outweighs negativity. Addict Res Theory 2009;17:637-49.

37 Ganley BJ, Rosario DI. The smoking attitudes, knowledge, intent, and behaviors of adolescents and young adults: implications for nursing practice. I Nurs Educ Pract 2013;3:40-50. 